\title{
Oude reflexen loslaten
}

Zelforganisatie in de zorg is 'in'. Het lijkt iets nieuws, maar deze organisatievorm is eigenlijk al begonnen in de jaren zeventig van de vorige eeuw, toen ziekenhuizen de teamverpleging invoerden, waardoor er een directere betrokkenheid ontstond tussen verpleegkundigen en patiënten.

In andere sectoren, zoals de auto-industrie, hadden bestuurders al eerder gekozen voor een teamgerichte aanpak. In de jaren negentig ontstonden de zelfsturende teams en begin deze eeuw kreeg de 'lean'-filosofie voet aan de grond: om verspilling tegen te gaan en de kwaliteit en het resultaat te verbeteren werden overbodige schakels en controles uit het productieproces gehaald.

Zelforganisatie in de zorg wil zeggen dat de regie bij de cliënt ligt en dat er regelruimte is voor de professional.
Maar zelforganisatie heeft ook sturing nodig, betogen Maartje Op de Coul, Helen van Tol en Guus de Vries in de jongste publicatie van DEV Organisatieadviseurs.

In kort bestek en heldere taal leggen ze uit wat zelforganisatie voor bestuurders betekent. "De paradox is dat je verder weg lijkt te staan van de basis en tegelijkertijd dichter bij de uitvoering moet komen. De kunst is om op je handen te zitten en op het juiste moment het juiste te doen. De oude reflexen van zelf ingrijpen of oplossen moet je loslaten."

Ht boek Zelforganisatie vraagt besturing behandelt achtereenvolgens de motieven voor zelforganisatie, het besturingsconcept, de fases van het veranderingsproces, de verschillende rollen van de bestuurder en ten slotte de rol van de toezichthouder.

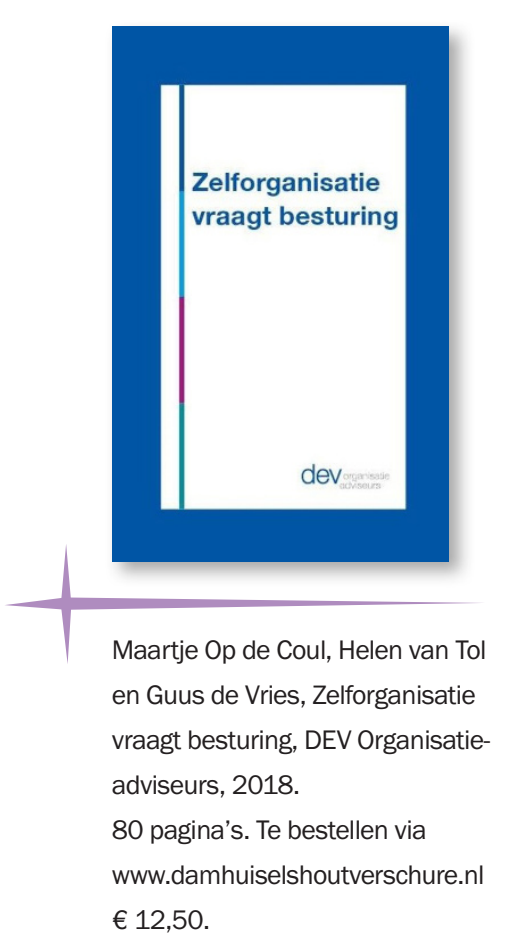
$€ 12,50$.

\section{Verbeter je geheugen}

Wil je op een speelse en toch serieuze manier je geheugen, aandacht en verbeeldingskracht trainen? Dan is Breinbootcamp een aanrader.

De Russische auteur Denis Bukin schreef dit boek - oorspronkelijke titel Spy School - toen hij ontdekte over welke enorme geheugencapaciteit spionnen beschikken. Dat moeten gewone mensen ook kunnen, dacht hij.

Breinbootcamp is opgezet als een spionnencursus. Net zoals een KGB-agent, in kleine stapjes, steeds moeilijker, leer je je geheugen en aandacht te trainen. Tussendoor geeft Bukin interessante informatie over onthouden, herinneren en vergeten, zoals over interferentie: het verschijn- sel dat je soortgelijke herinneringen met elkaar kunt verwarren. Of over het Zeigarnik-effect, wat wil zeggen dat je nog niet voltooide of onderbroken taken beter onthoudt dan afgemaakte taken. In bondige en toegankelijke taal krijg je praktisch psychologische kennis voorgeschoteld, bijvoorbeeld hoe je het beste gezichten en namen kunt onthouden, wat je vergeetcurve is of hoe je het beste je agenda kunt afstemmen op het specifieke ritme van je lichaam.

Het boek staat bomvol oefeningen die je vrijwel allemaal gewoon vanachter je bureau kunt doen. Geef jezelf een training, gun jezelf de tijd. Je geheugen knapt er enorm van op.

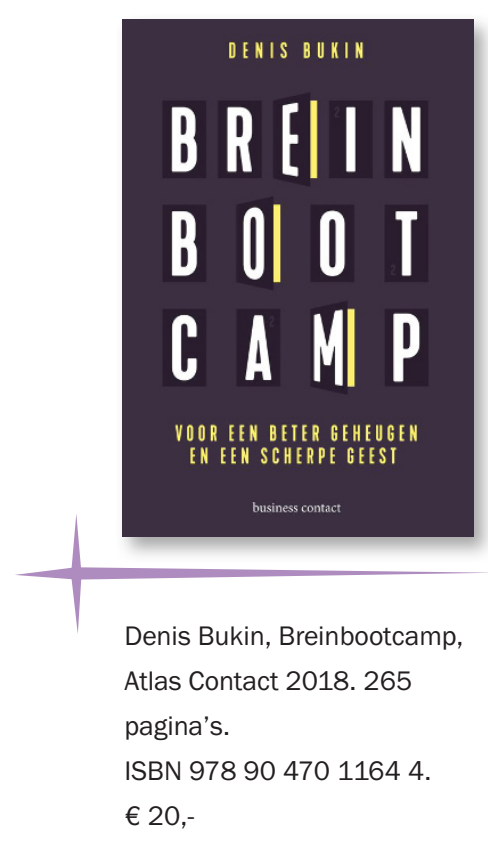

